\title{
Over-expression of nuclear factor- $\kappa B$ family genes and inflammatory molecules is related to chronic obstructive pulmonary disease
}

This article was published in the following Dove Press journal: International Journal of COPD

\author{
Liting Zhou' \\ Ying Liu ${ }^{2}$ \\ Xin Chen' \\ Shuyue Wang ${ }^{3}$ \\ Hongbo Liu' \\ Tianrong Zhang' \\ Yuezhu Zhang' \\ Qi Xu' \\ Xu Han' \\ Yaming Zhao' \\ Xinyue Song' \\ Lin $\mathrm{Ye}^{\prime}$
}

'Department of Occupational and Environmental Health, School of Public Health, Jilin University, Changchun, China; ${ }^{2}$ Department of Respiratory Medicine, The First Hospital of Jilin University, Jilin University, Changchun, China; ${ }^{3}$ Department of Emergency, ChinaJapan Union Hospital, Jilin University, Changchun, China
Correspondence: Lin Ye

Department of Occupational and Environmental Health, School of Public Health, Jilin University, II63 Xin Min Street, Changchun I3002I, China

Tel +86 43I 856I 9453

Fax+86 43। 856I 9I5 I

Email jlyelin@।63.com
Background: Nuclear factor- $\kappa \mathrm{B}(\mathrm{NF}-\kappa \mathrm{B})$ signaling plays essential roles in inflammatory responses. However, whether the expression levels of NF- $\kappa \mathrm{B}$ family genes affect inflammatory responses is unclear. Moreover, little is known regarding the association between NF- $\kappa \mathrm{B}$ family genes expression and the pathogenesis of chronic obstructive pulmonary disease (COPD). The present study was undertaken to assess the relationship between the expression levels of NF- $\mathrm{KB}$ family genes mRNA and of inflammatory markers relevant to COPD pathogenesis.

Methods: A total of 186 unrelated patients with acute exacerbations of COPD and 180 healthy controls were recruited. Total RNA was extracted from the peripheral fasting blood of each subject using trizol reagent. The mRNA levels of NF- $\kappa B$ family genes $(N F-\kappa B 1, N F-\kappa B 2$ and $c-R E L)$ were measured by real-time quantitative polymerase chain reaction. The serum levels of cyclooxygenase-2 (COX-2), C-reactive protein, interleukin (IL)-1 $\beta$, IL-6, IL-8, IL-12 and tumor necrosis factor- $\alpha$ were measured with enzyme-linked immunosorbent assay kits.

Results: The relative mRNA levels of the NF- $\kappa B$ family genes and the levels of inflammatory molecules were significantly higher in the COPD group than in the control group after adjustment for smoking. The IL-1 $\beta$, IL-8 and COX-2 levels were significantly lower in the $N F-\kappa B 2$ under-expression subgroup as compared to the $N F-\kappa B 2$ over-expression subgroup. The COX-2 level was significantly lower $(P<0.05)$ in the $c-R E L$ under-expression subgroup as compared to the $c-R E L$ over-expression subgroup.

Conclusion: $N F-\kappa B 2$ over-expression was associated with IL-1 $\beta$, IL-8 and COX-2 levels, whereas $c-R E L$ over-expression was associated with COX-2 level. Over-expression of both $N F-\kappa B 2$ and $c-R E L$ was found to be related to COPD.

Keywords: chronic obstructive pulmonary disease, inflammation, $\mathrm{NF}-\kappa \mathrm{B}$, gene expression

\section{Introduction}

COPD is the fourth leading cause of death worldwide and ranks among the primary causes of disability in developed countries. ${ }^{1}$ The GOLD predicts that COPD will rise from the fourth to the third leading cause of death worldwide by $2020 .^{2}$

COPD is a chronic systemic inflammatory disease, characterized by persistent respiratory symptoms and chronic airflow limitation. Inflammation is the most important factor in COPD pathogenesis. The most common causes of mortality in patients with COPD, respiratory insufficiency and cardiovascular complications, are attributed to systemic inflammation. ${ }^{3}$ Systemic inflammation can be assessed on the basis of inflammatory markers such as CRP, ILs, TNF- $\alpha$ and COX-2. ${ }^{4}$ Previous studies have demonstrated that these inflammatory molecules are involved in the pathogenesis of COPD. For example, IL-1 $\beta$ is a key factor in immune response, ${ }^{5}$ IL- 8 is involved in 
inflammatory cell recruitment ${ }^{6-9}$ and COX-2 expression is associated with recruitment of $\mathrm{T}$ cells, macrophages and neutrophils to the lung. ${ }^{10}$

The systemic inflammatory process in COPD involves both innate and adaptive immunity. ${ }^{11} \mathrm{NF}-\kappa \mathrm{B}$ family genes regulate genes required for both the innate and adaptive immune responses. ${ }^{12,13}$ Activation of the NF- $\kappa$ B family plays a central role in regulating the process of inflammation. $\mathrm{NF}-\kappa \mathrm{B}$ signaling can be activated by inflammatory molecules; conversely, activated NF- $\kappa \mathrm{B}$ signaling can stimulate the secretion of more inflammatory molecules. When the NF- $\kappa \mathrm{B}$ signaling pathway is blocked, the expression of TNF- $\alpha$ and IL-6 is downregulated. ${ }^{14,15}$

$\mathrm{NF}-\kappa \mathrm{B}$ signaling is well known to play essential roles in inflammatory responses. However, whether the expression levels of NF- $\kappa \mathrm{B}$ family genes affect inflammatory responses is unclear. Furthermore, little is known regarding the association of NF- $\mathrm{KB}$ family genes expression levels with the pathogenesis of COPD.

In this study, to explore the relationship among the mRNA expression of NF- $\kappa B$ family genes, levels of inflammatory molecules and COPD pathogenesis, we detected the mRNA levels of NF- $\kappa \mathrm{B}$ family genes $(N F-\kappa B 1, N F-\kappa B 2$ and $c-R E L)$ and the levels of serum inflammatory molecules (COX-2, CRP, IL-1 $\beta$, IL-6, IL-8, IL-12 and TNF- $\alpha$ ) in COPD patients and healthy controls.

\section{Methods}

\section{Subjects}

A total of 186 unrelated patients with acute exacerbation of COPD were recruited from The First Hospital of Jilin University between 2013 and 2014. COPD was defined on the basis of the diagnostic standards for COPD from the American Thoracic Society with post-bronchodilator FEV $\mathrm{F}_{1}$ FVC $<70 \%$. Patients with complications of other diseases were excluded. The disease severity was assessed to stratify patients on the basis of moderate, severe and very severe lung function according to the recommended criteria from GOLD. Control subjects $(n=180)$, residing in the same geographical area as the COPD group, were randomly selected during their routine checkups as part of their annual body examinations. They were classified as healthy controls on the basis of the results of physical examination coupled with the absence of any reasons to suspect COPD.

Every subject provided a written informed consent and was well informed of the study protocol. The study was approved by the ethics committee of the School of Public Health, Jilin University, Changchun, China. Peripheral venous fasting blood was collected in two tubes, one containing disodium-EDTA as an anticoagulant, from which extraction was performed immediately, and the other containing no anticoagulant, from which the blood was used for separation of serum.

\section{mRNA levels of NF- $\kappa B$ family genes (NF- $\kappa B I, N F-\kappa B 2$ and $c-R E L$ )}

Total RNA was extracted from the peripheral blood of each subject using trizol reagent (Takara Biomedical Technology, Beijing, China) according to the manufacturer's protocol. Total RNA quantity was measured with an ultraviolet spectrophotometer (BioPhotometer plus; Eppendorf AG, Hamburg, Germany). RNA integrity was assessed through electrophoresis on an agarose gel. First-strand cDNA synthesis was carried out on 500 ng of total RNA, using a Superscript II first-strand synthesis kit for reverse transcription PCR (Takara Biomedical Technology), according to the manufacturer's protocol. Finally, $2 \mu \mathrm{L}$ of cDNA was used for real-time quantitative PCR.

Levels of mRNAs of NF- $\kappa \mathrm{B}$ family genes $(N F-\kappa B 1$, $N F-\kappa B 2$ and $c-R E L$ ) were measured in samples using a realtime quantitative PCR kit (Takara Biomedical Technology), according to the manufacturer's protocol. The samples were prepared in a volume of $25 \mu \mathrm{L}$, containing $2 \mu \mathrm{L}$ cDNA, 12.5 $\mu \mathrm{L}$ SYBR Premix Ex Taq ${ }^{\mathrm{TM}}(2 \times), 0.5 \mu \mathrm{L}$ PCR reverse primer $(10 \mu \mathrm{M}), 0.5 \mu \mathrm{L}$ PCR forward primer $(10 \mu \mathrm{M}), 0.5 \mu \mathrm{L}$ ROX Reference Dye II $(50 \times)$ and $9 \mu \mathrm{LdH}_{2} \mathrm{O}$. Then, the mixture was denatured at $95^{\circ} \mathrm{C}$ for 5 minutes, and subjected to 40 cycles at $95^{\circ} \mathrm{C}(5$ seconds $)$ and $60^{\circ} \mathrm{C}$ ( 35 seconds $)$ before a final incubation at $95^{\circ} \mathrm{C}(15$ seconds $)$. Finally, all primers were designed to have an annealing temperature of $60^{\circ} \mathrm{C}$. The primers are shown in Table 1.

All samples were run in triplicate. Wells without template, but with pure water, were included as negative controls. $N F-\kappa B 1, N F-\kappa B 2$ and $c-R E L$ mRNA expression levels were quantified via the $2^{-\Delta \mathrm{CT}}$ method.

\section{Serum inflammatory cytokine levels}

Blood samples were separated by centrifugation at 3,500 rpm for 10 minutes. Serum samples were stored at $-80^{\circ} \mathrm{C}$ until

Table I Primer sequences of candidate genes

\begin{tabular}{lll}
\hline Gene name & Primer & Sequence \\
\hline$\beta$-actin & Forward & 5'-CTGGAACGGTGAAGGTGACA-3' \\
& Reverse & 5'-CGGCCACATTGTGAACTTTG-3' \\
NF- KBI & Forward & 5'-CACAAGGCAGCAAATAGACGAG-3' \\
& Reverse & 5'-TGGGGCATTTTGTTGAGAGTT-3' \\
NF-KB2 & Forward & 5'-GGCTGGTGCTGACATCCAT-3' \\
& Reverse & 5'-CTGCTTCGGGTGTCCTTCTC-3' \\
C-REL & Forward & 5'-GACGACTGCTCTTCCTCCTGTT-3' \\
& Reverse & 5'-TCATCTCCTCCTCTGACACTTCC-3' \\
\hline
\end{tabular}


testing. COX-2, CRP, IL-1 $\beta$, IL-6, IL-8, IL-12 and TNF- $\alpha$ serum levels were measured using the commercially available enzyme-linked immunosorbent assay kits (R\&D Systems, Inc., Minneapolis, MN, USA), according to the manufacturer's instructions.

\section{Statistical analysis}

Statistical analysis was carried out using the SPSS 16.0 software. The results of the normal distribution test showed that all continuous variables were normally distributed. Hence, data are expressed as mean \pm standard deviation. Data were compared with Student's $t$-test or analysis of variance for continuous variables and chi-square test for categorical variables (sex and smoking). Logistic regression models were used to adjust for smoking and to calculate the ORs and $95 \%$ CIs. A two-sided $P$-value $<0.05$ was considered statistically significant.

\section{Results}

\section{Characteristics of study subjects}

Table 2 lists the demographic and clinical characteristics of the 186 patients with COPD of varying severity and 180 control subjects. There was no statistically significant difference between the COPD group and the control group with respect to the frequency distribution of age, and the sex distribution was unbiased (all $P>0.05$ ). Compared to the control group, the COPD group had more smokers. With increase in disease severity, the number of male patients and smoking patients was significantly higher.

\section{mRNA levels of NF- $\kappa B$ family genes}

The relative mRNA levels of the NF- $\kappa B$ family genes were significantly higher in the COPD group than in the control group (Figure 1). To explore the relationship between the mRNA levels of NF- $\kappa$ B family genes and disease severity, the relative mRNA levels of $\mathrm{NF}-\kappa \mathrm{B}$ family genes among patients with different severities of COPD were further analyzed. However, there were no significant differences among patients with different severities of COPD (Figure 2).

\section{Levels of serum inflammatory molecules}

There was a statistically significant difference between the COPD group and the control group with respect to the levels of serum inflammatory molecules $(P<0.001)$ (Table 3$)$. The levels of all the measured inflammatory molecules were significantly higher in the COPD group than in the control group. After adjustment for smoking, the OR and 95\% CI for COX-2, CRP, IL-1 $\beta$, IL-6, IL-8, IL-12 and TNF- $\alpha$ were 1.328 (1.249-1.411), 6.088 (4.162-8.904), 2.334 (1.8452.951), 1.818 (1.590-2.079), 1.221 (1.169-1.274), 1.495 (1.372-1.628) and 1.530 (1.388-1.687), respectively.

Then, patients and controls were divided into smoker and nonsmoker groups to analyze the differences in levels of inflammatory molecules. The levels of inflammatory molecules were significantly higher in smoker and nonsmoker patients than in healthy smokers and nonsmokers (Table 4).

To explore the relationship between the levels of serum inflammatory molecules and disease severity, the levels of inflammatory molecules among patients with different severities of COPD were further analyzed. However, there were no significant differences among patients with different severities of COPD (Table 5).

\section{Relationship between expression of NF- $\kappa B$ family genes and inflammatory molecules}

To determine the relationship between the expression of $\mathrm{NF}-\kappa \mathrm{B}$ family genes and inflammatory molecules, we conducted a subgroup analysis based on the NF- $\kappa$ B expression

Table 2 Baseline characteristics of the COPD group and control group

\begin{tabular}{|c|c|c|c|c|c|c|c|}
\hline & \multicolumn{4}{|c|}{ COPD group $(n=186)$} & \multirow{2}{*}{$\begin{array}{l}\text { Control group } \\
(n=180)(\%)\end{array}$} & \multirow[t]{2}{*}{$t / \chi^{2}$} & \multirow[t]{2}{*}{$P$-value } \\
\hline & $\begin{array}{l}\text { Moderate } \\
(n=53)(\%)\end{array}$ & $\begin{array}{l}\text { Severe } \\
(n=60)(\%)\end{array}$ & $\begin{array}{l}\text { Very severe } \\
(n=73)(\%)\end{array}$ & Total (\%) & & & \\
\hline Age & $62.21 \pm 13.22$ & $63.25 \pm 10.92$ & $59.43 \pm 9.62$ & $63.17 \pm 11.54$ & $63.03 \pm 11.53$ & 0.115 & 0.909 \\
\hline \multicolumn{8}{|l|}{ Sex } \\
\hline Male & $24(45.3)$ & $30(50.0)$ & 43 (58.9) & 97 (52.2\%) & 77 (42.8) & 3.222 & 0.073 \\
\hline Female & $29(54.7)$ & $30(50.0)$ & $30(4 I . I)$ & 89 (47.8\%) & 103 (57.2) & & \\
\hline \multicolumn{8}{|l|}{ Smoking } \\
\hline No & $35(66.0)$ & $36(60.0)$ & 35 (47.9) & 106 (53.0\%) & 135 (75.0) & 13.195 & $<0.001$ \\
\hline Yes & $18(34.0)$ & $24(40.0)$ & $38(52.1)$ & $80(47.0 \%)$ & $45(25.0)$ & & \\
\hline Pack years & $45.00 \pm 44.75$ & $40.00 \pm 27.50$ & $20.00 \pm 30.00$ & & & & \\
\hline
\end{tabular}

Notes: Age and pack years are expressed as mean \pm standard error of the mean. The difference in age between the COPD group and the control group was compared with Student's $t$-test. Sex and smoking are expressed as $\mathrm{n}(\%)$. The differences were compared with Pearson's chi-square test.

Abbreviation: COPD, chronic obstructive pulmonary disease. 


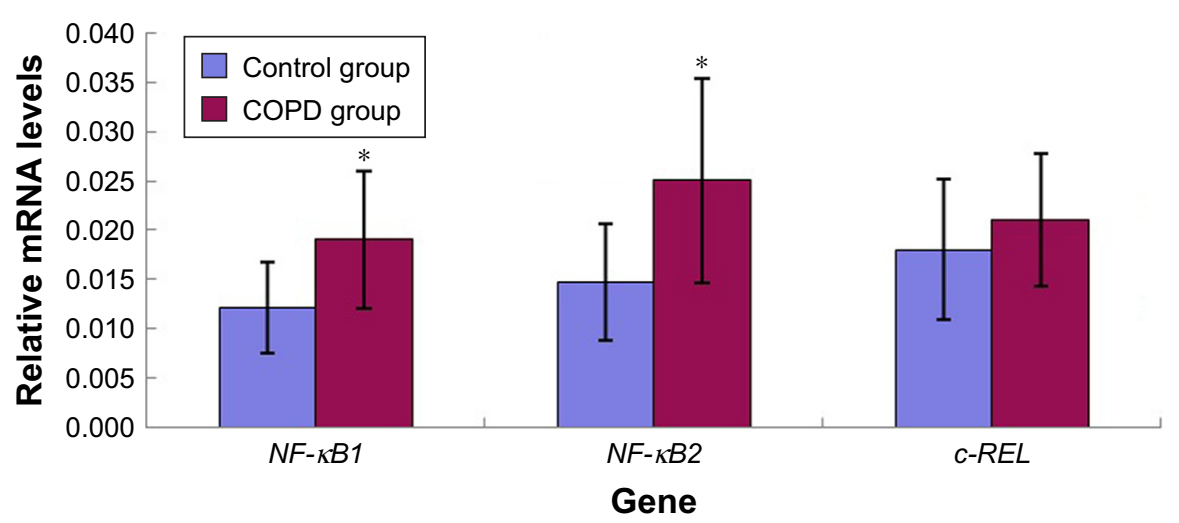

Figure I Relative mRNA levels of NF- $\kappa B$ family genes in COPD group and control group. Relative mRNA levels of NF- $\mathrm{KB}$ family genes were expressed as the mean value \pm standard deviation. $* P<0.05$, compared with the control group.

Abbreviations: $\mathrm{NF}-\kappa \mathrm{B}$, nuclear factor- $\mathrm{\kappa B}$; COPD, chronic obstructive pulmonary disease.

level. If a patient's mRNA level was higher than the average level of the controls, we placed the patient in an overexpression subgroup; otherwise, the patient was placed in an under-expression subgroup. As shown in Figure 3, the levels of IL-1 $\beta$, IL-8 and COX-2 were significantly different between the $N F-\kappa B 2$ over-expression and under-expression subgroups $(P<0.05)$. The IL-1 $\beta$, IL-8 and COX-2 levels were significantly lower in the $N F-\kappa B 2$ under-expression subgroup than in the $N F-\kappa B 2$ over-expression subgroup. The COX-2 levels were significantly different between the $c$-REL over-expression subgroup and the $c-R E L$ underexpression subgroup $(P<0.05)$. Compared to the $c-R E L$ over-expression subgroup, the COX-2 level was significantly lower in the $c-R E L$ under-expression subgroup.

\section{Discussion}

The inflammatory response differs in different phases of the disease in COPD patients. Therefore, we ensured that the COPD patients we recruited were in the acute exacerbation phase.
Previous studies have suggested that smoking is an independent risk factor for COPD. In this case-control study, we matched COPD group and control group by age and sex. Smoking history was investigated as well. Compared with the control group, the COPD group contained more smokers. With increasing severity of the disease, the number of male patients and smoking patients significantly increased. Our results confirmed that smoking is associated with COPD as well as with severity.

The main pathological features of COPD are systemic inflammation in the airways, pulmonary parenchyma and vessels, as mediated by inflammatory molecules. ${ }^{16-19}$ The most important inflammatory molecules, COX-2, CRP, IL-1 $\beta$, IL-6, IL-8, IL-12 and TNF- $\alpha$, are elevated in the serum in COPD patients and are correlated with the disease onset, disease progression, disease severity, etc. ${ }^{20-22}$

The NF- $\mathrm{KB}$ pathway is one of the most important cellular signal transduction pathways involved in the immune function and controlling inflammation. The expression levels of

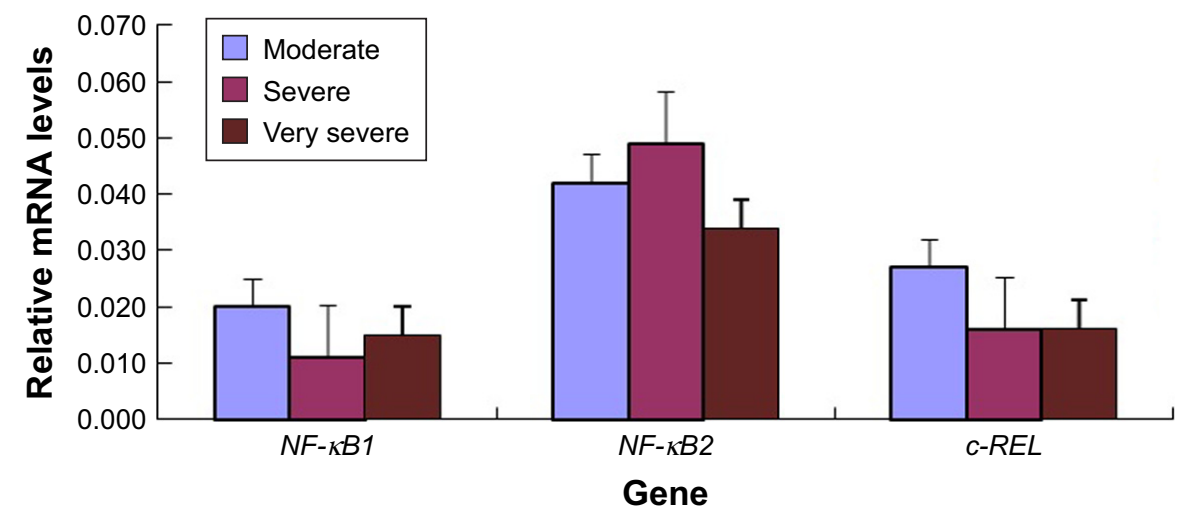

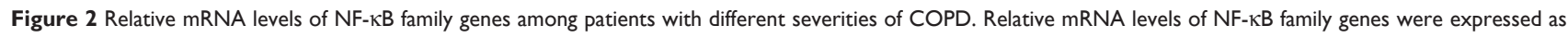
the mean value \pm standard deviation.

Abbreviations: NF- $\kappa \mathrm{B}$, nuclear factor- $\mathrm{KB}$; COPD, chronic obstructive pulmonary disease. 
Table 3 Differences in inflammatory molecules levels between COPD group and control group (mean \pm standard deviation)

\begin{tabular}{|c|c|c|c|c|c|}
\hline $\begin{array}{l}\text { Inflammatory } \\
\text { molecules }\end{array}$ & $\begin{array}{l}\text { COPD group } \\
(n=186)\end{array}$ & $\begin{array}{l}\text { Control group } \\
(n=180)\end{array}$ & $\boldsymbol{t}$ & $P$-value & SD $(95 \% C I)^{a}$ \\
\hline COX-2 (U/L) & $71.60 \pm 9.40$ & $50.64 \pm 0.09$ & 21.508 & $<0.001$ & $1.328(1.249-1.41 \mathrm{I})$ \\
\hline CRP (mg/L) & $6.20 \pm 1.21$ & $4.15 \pm 1.03$ & 17.256 & $<0.001$ & $6.088(4.162-0.904)$ \\
\hline $\mathrm{IL}-\mathrm{I} \beta(\mathrm{pg} / \mathrm{mL})$ & $43.33 \pm 5.70$ & $28.60 \pm 5.07$ & 25.894 & $<0.001$ & $2.334(1.845-2.951)$ \\
\hline IL-6 (pg/mL) & $29.90 \pm 5.32$ & $20.57 \pm 3.37$ & 19.858 & $<0.010$ & $1.818(1.590-2.079)$ \\
\hline IL-8 (pg/mL) & $76.28 \pm 13.29$ & $49.99 \pm 10.71$ & 20.661 & $<0.001$ & $1.221(1.169-1.274)$ \\
\hline IL-I2 (pg/mL) & $30.42 \pm 5.72$ & $21.74 \pm 4.05$ & 16.609 & $<0.001$ & $1.495(1.372-1.628)$ \\
\hline TNF- $\alpha$ (pg/mL) & $45.35 \pm 8.25$ & $29.24 \pm 4.25$ & 23.287 & $<0.001$ & $1.530(1.388-1.687)$ \\
\hline
\end{tabular}

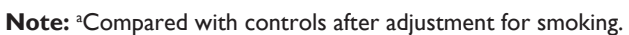

Abbreviations: COPD, chronic obstructive pulmonary disease; SD, standard deviation; CI, confidence interval; COX-2, cyclooxygenase-2; CRP, C-reactive protein; IL, interleukin; TNF- $\alpha$, tumor necrosis factor- $\alpha$.

inflammatory molecules are regulated by the NF- $\kappa B$ signaling pathway. Inhibition of the NF- $\mathrm{\kappa B}$ signaling pathway may be a potent strategy for the treatment of human inflammatory diseases. $^{23,24}$

In this study, we found that the levels of inflammatory cytokines, including COX-2, CRP, IL-1 $\beta$, IL-6, IL-8, IL-12 and TNF- $\alpha$, and the mRNA levels of NF- $\mathrm{KB}$ family genes were significantly higher in patients with COPD than in controls. Because systemic inflammation in COPD can be influenced by smoking, we adjusted for smoking with a regression model and divided both patients and controls into smoker and nonsmoker groups to investigate the reason for this association. The results showed that after adjustment for smoking, the levels of all assayed inflammatory molecules remained significantly higher in the COPD group. Moreover, the levels of inflammatory molecules were significantly higher in smoker and nonsmoker patients than in healthy smokers and nonsmokers. These results indicated that the elevated levels of inflammatory cytokines and mRNA levels of NF- $\mathrm{KB}$ family genes are major factors in COPD.

To explore the relationship among the mRNA levels of NF- $\kappa B$ family genes, levels of serum inflammatory molecules and disease severity, the relative mRNA levels of
NF- $\kappa \mathrm{B}$ family genes and the levels of serum inflammatory molecules in patients with varying COPD severity were further analyzed. However, we did not find any significant differences among patients with different severities of COPD. This result may have occurred because the COPD subjects were in acute exacerbation phases. Patients with acute exacerbation of COPD are characterized by a worsening of the respiratory symptoms, dyspnea and cough and/or sputum exceeding the usual day-to-day variations. When patients were in the acute exacerbation phases, the NF- $\mathrm{\kappa B}$ signaling pathway in the lung was activated, and inflammation was markedly increased. In addition, this process was not associated with lung function and disease severity. These results led us to hypothesize that the mRNA expression of NF- $\mathrm{kB}$ family genes might be related to the expression of inflammatory molecules, and might influence the progression of COPD. To assess the relationships among the expression of NF- $\mathrm{KB}$ family genes and inflammatory molecules, we conducted a subgroup analysis based on the NF- $\mathrm{KB}$ expression level. The results showed that compared with $N F-\kappa B 2$ over-expression subgroup, the IL- $1 \beta$, IL- 8 and COX-2 levels were significantly lower in $N F-\kappa B 2$ under-expression subgroup; compared with $c$-REL over-expression subgroup,

Table 4 Differences in inflammatory molecules levels between smokers and nonsmokers with or without COPD

\begin{tabular}{|c|c|c|c|c|c|c|}
\hline \multirow{2}{*}{$\begin{array}{l}\text { Inflammatory } \\
\text { molecules }\end{array}$} & \multicolumn{2}{|c|}{ Control group } & \multicolumn{2}{|l|}{ COPD group } & \multirow[t]{2}{*}{$\boldsymbol{F}$} & \multirow[t]{2}{*}{$P$-value } \\
\hline & Nonsmoker & Smoker & Nonsmoker & Smoker & & \\
\hline COX-2 (U/L) & $51.09 \pm 8.74$ & $49.30 \pm 10.06$ & $71.20 \pm 9.56^{\mathrm{a}, \mathrm{b}}$ & $72.14 \pm\left. 9.2\right|^{a, b}$ & 154.662 & $<0.001$ \\
\hline CRP (mg/L) & $4.13 \pm 1.05$ & $4.21 \pm 0.96$ & $6.09 \pm 1.16^{\mathrm{a}, \mathrm{b}}$ & $6.34 \pm 1.26^{\mathrm{a}, \mathrm{b}}$ & 100.269 & $<0.001$ \\
\hline IL-I $\beta$ (pg/mL) & $28.48 \pm 5.05$ & $28.97 \pm 5.17$ & $42.90 \pm 5.53^{\mathrm{a}, \mathrm{b}}$ & $43.90 \pm\left. 5.9\right|^{a, b}$ & 223.974 & $<0.001$ \\
\hline IL-6 (pg/mL) & $20.55 \pm 3.37$ & $20.63 \pm 3.44$ & $29.5 \mathrm{I} \pm 4.97^{\mathrm{a}, \mathrm{b}}$ & $30.42 \pm 5.75^{\mathrm{a}, \mathrm{b}}$ & 131.998 & $<0.010$ \\
\hline IL-8 (pg/mL) & $49.90 \pm 10.73$ & $50.28 \pm 10.76$ & $77.75 \pm 13.10^{\mathrm{a}, \mathrm{b}}$ & $74.31 \pm 13.37^{\mathrm{a}, \mathrm{b}}$ & 144.158 & $<0.001$ \\
\hline IL- 12 (pg/mL) & $21.82 \pm 3.94$ & $2 I .5 I \pm 4.4 I$ & $29.75 \pm 5.24^{\mathrm{a}, \mathrm{b}}$ & $3 \mathrm{I} .3 \mathrm{I} \pm 6.23^{\mathrm{a}, \mathrm{b}}$ & 94.101 & $<0.001$ \\
\hline TNF- $\alpha$ (pg/mL) & $29.19 \pm 4.23$ & $29.38 \pm 4.35$ & $44.68 \pm 7.8 \mathrm{I}^{\mathrm{a}, \mathrm{b}}$ & $46.23 \pm 8.78^{\mathrm{a}, \mathrm{b}}$ & 181.852 & $<0.001$ \\
\hline
\end{tabular}

Notes: a $P<0.05$, compared with nonsmoker controls. ${ }^{b} P<0.05$, compared with smoker controls.

Abbreviations: COPD, chronic obstructive pulmonary disease; COX-2, cyclooxygenase-2; CRP, C-reactive protein; IL, interleukin; TNF- $\alpha$, tumor necrosis factor- $\alpha$. 
Table 5 Differences in inflammatory molecules levels among patients with different severities of COPD

\begin{tabular}{|c|c|c|c|c|c|}
\hline \multirow{2}{*}{$\begin{array}{l}\text { Inflammatory } \\
\text { molecules }\end{array}$} & \multicolumn{3}{|c|}{ Different severities of COPD } & \multirow[t]{2}{*}{$\boldsymbol{F}$} & \multirow[t]{2}{*}{$P$-value } \\
\hline & Moderate $(n=53)$ & Severe $(n=60)$ & Very severe $(n=73)$ & & \\
\hline $\operatorname{coX}-2(\mathrm{U} / \mathrm{L})$ & $70.98 \pm 10.13$ & $71.49 \pm 9.41$ & $72.64 \pm 8.75$ & 0.374 & 0.689 \\
\hline CRP (mg/L) & $6.07 \pm 1.16$ & $6.36 \pm 0.94$ & $6.22 \pm 1.44$ & 0.583 & 0.560 \\
\hline $\mathrm{IL}-\mathrm{I} \beta(\mathrm{pg} / \mathrm{mL})$ & $43.89 \pm 5.45$ & $42.61 \pm 5.63$ & $43.33 \pm 5.44$ & 0.537 & 0.586 \\
\hline IL-6 (pg/mL) & $28.48 \pm 4.90$ & $30.53 \pm 4.97$ & $30.53 \pm 6.46$ & 1.753 & 0.177 \\
\hline IL-8 (pg/mL) & $74.77 \pm 13.79$ & $76.90 \pm 12.91$ & $74.97 \pm 12.86$ & 0.336 & 0.715 \\
\hline IL-I2 (pg/mL) & $28.76 \pm 5.03$ & $30.85 \pm 5.27$ & $31.03 \pm 6.95$ & 1.768 & 0.175 \\
\hline TNF- $\alpha$ (pg/mL) & $43.78 \pm 8.00$ & $46.97 \pm 7.46$ & $45.65 \pm 9.70$ & 1.350 & 0.263 \\
\hline
\end{tabular}

Abbreviations: COPD, chronic obstructive pulmonary disease; COX-2, cyclooxygenase-2; CRP, C-reactive protein; IL, interleukin; TNF- $\alpha$, tumor necrosis factor- $\alpha$.

A

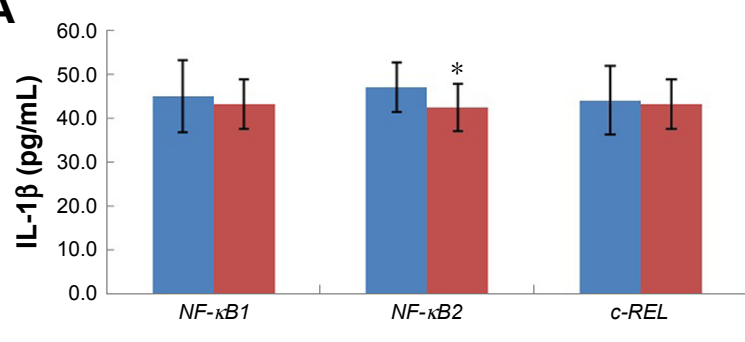

C

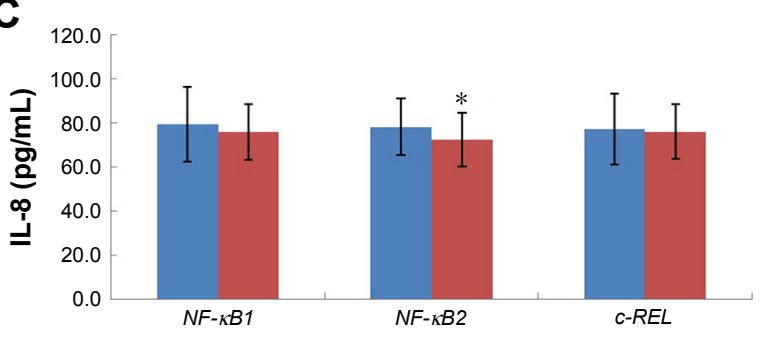

E

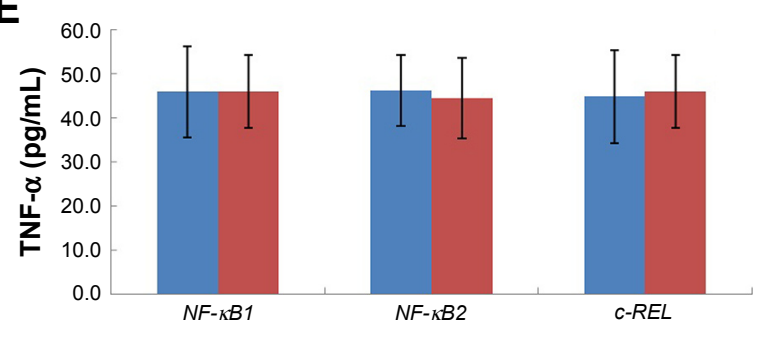

B

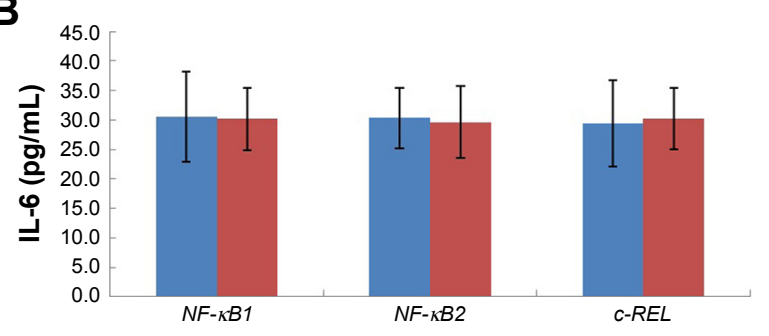

D

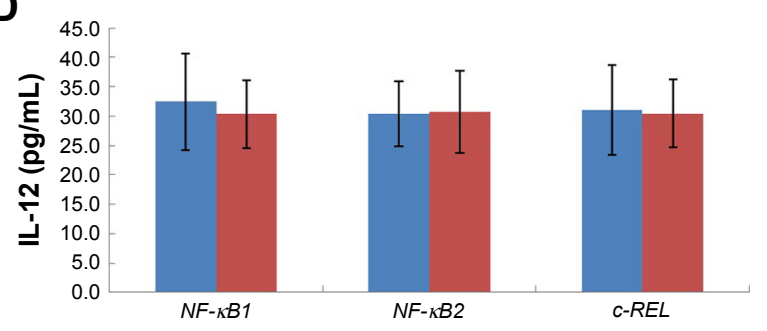

F

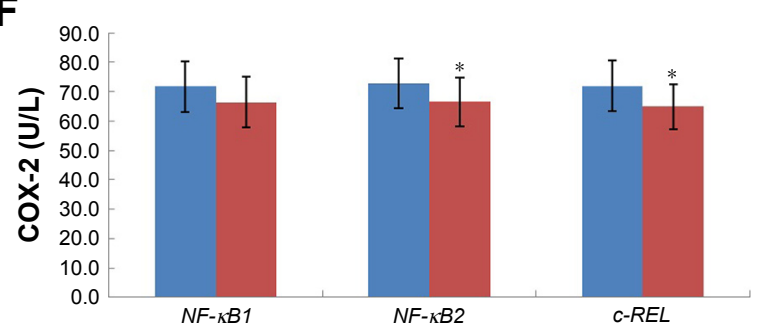

G

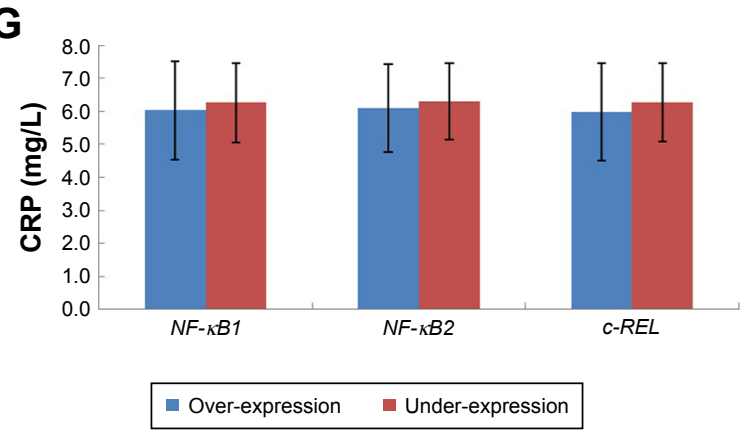

Figure 3 Subgroup analysis of inflammatory molecules levels based on the mRNA expression levels of NF-KB family genes in patients with COPD: (A) IL-I $\beta$, (B) IL-6, (C) IL-8, (D) IL-12, (E) TNF- $\alpha$, (F) COX-2 and (G) CRP. *P < 0.05, compared with over-expression subgroup.

Abbreviations: NF- $\mathrm{KB}$, nuclear factor- $\mathrm{KB}$; COPD, chronic obstructive pulmonary disease; IL, interleukin; TNF- $\alpha$, tumor necrosis factor- $\alpha$; COX-2, cyclooxygenase-2; CRP, C-reactive protein. 
the COX-2 level was significantly lower in $c-R E L$ underexpression subgroup. These results suggested that $N F-\kappa B 2$ over-expression correlated with IL-1 $\beta$, IL- 8 and COX-2, and $c-R E L$ over-expression correlated with COX-2.

$\mathrm{NF}-\kappa \mathrm{B}$ regulates various genes involved in immune response, inflammation, cell survival and development. ${ }^{25}$ Elevated mRNA levels of NF- $\kappa$ B family genes may promote the onset and progression of COPD. $N F-\kappa B 2$ is synthesized as a large precursor of the $100-\mathrm{kDa}$ protein (p100) precursor, which is processed by the proteasome to generate $\mathrm{p} 52$, corresponding to the amino-terminal half of p100. A study with p52 transgenic mice has suggested a causal role for sustained $N F-\kappa B 2$ activation in the development of inflammation and autoimmunity. ${ }^{26}$ Our study demonstrated that over-expression of $N F-\kappa B 2$ is associated with the levels of IL-1 $\beta$, IL- 8 and COX-2, and over-expression of $c-R E L$ is associated with the level of COX-2. The results indicated a potential relationship between the NF- $\kappa B$ family genes and the inflammation involved in COPD, and implied that over-expression of $N F-\kappa B 2$ and $c-R E L$ may be involved in the pathogenesis of COPD.

\section{Conclusion}

In conclusion, we confirmed that the expression of NF- $\kappa \mathrm{B}$ family genes and inflammatory cytokines was significantly higher in patients with COPD than in controls. Over-expression of $N F-\kappa B 2$ was associated with IL-1 $\beta$, IL-8 and COX-2 levels, whereas over-expression of $c-R E L$ was associated with COX-2 level. Over-expression of both $N F-\kappa B 2$ and $c-R E L$ was related to COPD.

\section{Abbreviations}

CI, confidence interval; COPD, chronic obstructive pulmonary disease; COX-2, cyclooxygenase-2; CRP, C-reactive protein; GOLD, Global Initiative for Chronic Obstructive Lung Disease; IL, interleukin; NF- $\kappa \mathrm{B}$, nuclear factor- $\kappa \mathrm{B}$; OR, odds ratio; PCR, polymerase chain reaction; TNF- $\alpha$, tumor necrosis factor- $\alpha$.

\section{Acknowledgments}

The authors would like to thank the people for their participation in the study. They would also like to thank The First Hospital of Jilin University for providing blood samples and detailed information about the participants. This work was sponsored by the Natural Science Foundation of China, Department of Science and Technology of Jilin Province (20150101208JC, 20160520159JH) and Medical Research
Support Plan of Norman Bethune Health Science Center (2013102010).

\section{Disclosure}

The authors report no conflicts of interest in this work.

\section{References}

1. Altaf M, Zubedi AM, Nazneen F, et al. Cost-effectiveness analysis of three different combinations of inhalers for severe and very severe chronic obstructive pulmonary disease patients at a tertiary care teaching hospital of South India. Perspect Clin Res. 2015;6:150-158.

2. Vestbo J, Hurd SS, Agustí AG, et al. Global strategy for the diagnosis, management, and prevention of chronic obstructive pulmonary disease: GOLD executive summary. Am J Respir Crit Care Med. 2013; 187:347-365.

3. Sin DD, Man SF. Why are patients with chronic obstructive pulmonary disease at increased risk of cardiovascular diseases? The potential role of systemic inflammation in chronic obstructive pulmonary disease. Circulation. 2003;107:1514-1519.

4. Ghobadi H, Fouladi N, Beukaghazadeh K, Ansarin K. Association of high sensitive CRP level and COPD assessment test scores with clinically important predictive outcomes in stable COPD patients. Tanaffos. 2015;14:34-41.

5. Barnes PJ. The cytokine network in chronic obstructive pulmonary disease. Am J Respir Cell Mol Biol. 2009;41:631-638.

6. van Eeden SF, Sin DD. Chronic obstructive pulmonary disease: a chronic systemic inflammatory disease. Respiration. 2008;75:224-238.

7. Sarir H, Henricks PA, van Houwelingen AH, Nijkamp FP, Folkerts G. Cells, mediators and Toll-like receptors in COPD. Eur J Pharmacol. 2008;585:346-353.

8. Celli BR, Barnes PJ. Exacerbations of chronic obstructive pulmonary disease. Eur Respir J. 2007;29:1224-1238.

9. Patel IS, Seemungal TA, Wilks M, Lloyd-Owen SJ, Donaldson GC, Wedzicha JA. Relationship between bacterial colonisation and the frequency, character, and severity of COPD exacerbations. Thorax. 2002;57:759-764.

10. Sheridan JA, Zago M, Nair P, et al. Decreased expression of the NF- $\kappa B$ family member RelB in lung fibroblasts from smokers with and without COPD potentiates cigarette smoke-induced COX-2 expression. Respir Res. 2015;16:54.

11. King PT. Inflammation in chronic obstructive pulmonary disease and its role in cardiovascular disease and lung cancer. Clin Transl Med. 2015;4:68

12. Medzhitov R. Recognition of microorganisms and activation of the immune response. Nature. 2007;449:819-826.

13. Vallabhapurapu S, Karin M. Regulation and function of NF-kappaB transcription factors in the immune system. Аnпи Rev Immunol. 2009;27: 693-733.

14. Hsuan CF, Hsu HF, Tseng WK, et al. Glossogyne tenuifolia extract inhibits TNF- $\alpha$-induced expression of adhesion molecules in human umbilical vein endothelial cells via blocking the NF-kB signaling pathway. Molecules. 2015;20:16908-16923.

15. Haseeb A, Khan NM, Ashruf OS, Haqqi TM. A polyphenol-rich pomegranate fruit extract suppresses NF- $\mathrm{KB}$ and IL-6 expression by blocking the activation of IKK $\beta$ and NIK in primary human chondrocytes. Phytother Res. 2017;31:778-782.

16. Joppa P, Petrasova D, Stancak B, Tkacova R. Systemic inflammation in patients with COPD and pulmonary hypertension. Chest. 2006;130: 326-333.

17. Sin DD, Man SF. Systemic inflammation and mortality in chronic obstructive pulmonary disease. Can J Physiol Pharmacol. 2007;85: $141-147$. 
18. Moermans C, Heinen V, Nguyen M, et al. Local and systemic cellular inflammation and cytokine release in chronic obstructive pulmonary disease. Cytokine. 2011;56:298-304.

19. Hacievliyagil SS, Mutlu LC, Temel I. Airway inflammatory markers in chronic obstructive pulmonary disease patients and healthy smokers. Niger J Clin Pract. 2013;16:76-81.

20. Arif E, Vibhuti A, Deepak D, Singh B, Siddiqui MS, Pasha MA. COX2 and p53 risk-alleles coexist in COPD. Clin Chim Acta. 2008;397: 48-50.

21. Chan KH, Yeung SC, Yao TJ, et al. COPD Study Group of the Hong Kong Thoracic Society: elevated plasma adiponectin levels in patients with chronic obstructive pulmonary disease. Int J Tuberc Lung Dis. 2010;14:1193-1200.

22. Sin DD, Man SF. Interleukin-6: a red herring or a real catch in COPD? Chest. 2008;133:4-6.
23. Sarkar FH, Li Y, Wang Z, Kong D. NF-kappaB signaling pathway and its therapeutic implications in human diseases. Int Rev Immunol. 2008;27:293-319.

24. Karin M, Greten FR. NF-kappaB: linking inflammation and immunity to cancer development and progression. Nat Rev Immunol. 2005;5: 749-759.

25. Mise-Omata S, Obata Y, Doi TS. p100, a precursor of NF- $\kappa B 2$, inhibits $\mathrm{c}-\mathrm{Rel}$ and reduces the expression of IL-23 in dendritic cells. Biochem Biophys Res Commun. 2014;453:332-337.

26. Wang Z, Zhang B, Yang L, Ding J, Ding HF. Constitutive production of NF-kappaB2 p52 is not tumorigenic but predisposes mice to inflammatory autoimmune disease by repressing Bim expression. J Biol Chem. 2008;283:10698-10706.

\section{Publish your work in this journal}

The International Journal of COPD is an international, peer-reviewed journal of therapeutics and pharmacology focusing on concise rapid reporting of clinical studies and reviews in COPD. Special focus is given to the pathophysiological processes underlying the disease, intervention programs, patient focused education, and self management protocols.

\section{Dovepress}

This journal is indexed on PubMed Central, MedLine and CAS. The manuscript management system is completely online and includes a very quick and fair peer-review system, which is all easy to use. Visit http://www.dovepress.com/testimonials.php to read real quotes from published authors. 